This is an unedited manuscript in press in the

$$
\text { Journal of Management Development }
$$

Please note that the published version will undergo minor additional editing in style and content. Please cite as:

Cao, L., Hirschi, A., \& Deller, J. (in press). Self-initiated expatriates and their career success. Journal of Managment Development.

\title{
Self-initiated Expatriates and Their Career Success
}

Lan Cao, Andreas Hirschi, Jürgen Deller

Leuphana University of Lüneburg

\section{Author Note}

Correspondence concerning this article should be addressed to Lan Cao, Institute for Strategic HR Management, Wilschenbrucher Weg 84a, 21335 Lüneburg, Germany. E-mail: lan.cao@leuphana.de 


\section{Title}

Self-initiated Expatriates and Their Career Success

\section{Purpose}

The paper provides conceptual clarity by distinguishing self-initiated expatriates (SIEs) from company-assigned expatriates (AEs), and skilled migrants; most importantly, it introduces an overarching conceptual framework based on career capital theory to explain SIEs' career success.

\section{Design/methodology/approach}

This conceptual framework is based on a review of the relevant literature on SIE, expatriation, career studies, cross-cultural studies, migration, and other related areas.

\section{Findings}

Protean career attitude, career networks, and cultural intelligence are identified as three major types of career capital influencing SIEs career success positively; the predicting relationships between these are mediated by cultural adjustment in the host country. Cultural distance acts as the moderator, which highlights the influence of macro-contextual factors on SIEs' career development.

\section{Research implications/ limitations}

The current paper applied career capital theory and did not integrate the impact of family and labor market situation on SIEs' career development. Further research should 1) test the proposed framework empirically, and 2) integrate the impact of family- and career-related factors into a holistic approach.

\section{Practical implications}


When constructing international talent acquisition and retention strategies, organizations and receiving countries should understand the different career development needs and provide SIEs with opportunities to increase career capital during expatriation. Furthermore, the current framework suggests how to adjust to the host country in order to meet career development goals.

\section{Originality/value}

The multi-level and sequential framework adds value by identifying specific types of career capital for SIEs and providing a conceptual underpinning for explaining how they interact and foster SIEs' career success. Moreover, the framework embraces SIEs from both developed and developing economies.

\section{Keywords}

Self-initiated expatriate, protean career, career success, career capital, network, skilled migrants 


\section{Introduction}

The globalized world economy and rapid technological progress demand increasing global mobility and flexibility in the workplace and workforce (OECD, 2008). More and more skilled individuals seek international career opportunities and expatriate themselves (Carr et al., 2005). Self-initiated expatriates (SIEs) are defined as employees who are not assigned to another country by an organization but have instead chosen to move to another country to work and live on their own arrangement (Tharenou and Caulfield, 2010). Due to talent shortages in many countries and the increasing demand for inter-culturally flexible employees with more differentiated skill sets (Deloitte, 2010), SIEs are strategically valuable human resources for multinational corporations (MNCs; Howe-Walsh and Schyns, 2010), and growing numbers are employed by organizations (Jokinen et al., 2008).

Following the publication of Inkson and colleagues (1997), which presented a new type of international career, interest in SIEs has proliferated. Research has concentrated on SIEs as a new field of study in human resource management (Suutari and Brewster, 2000, HoweWalsh and Schyns, 2010), comparisons between company-assigned expatriates (AEs) and SIEs (Jokinen et al., 2008, Doherty et al., 2011), repatriation (Harvey, 2009, Tharenou and Caulfield, 2010), and brain circulation (Saxenian, 2005). In the field of career studies, previous research studied motivation and drivers for self-initiated international careers (e.g. Cerdin and Pargneux, 2010), career barriers and career strategies (e.g. Al Ariss and Syed, 2011), and career capital (e.g. Jokinen et al., 2008).

Worldwide, many SIEs expatriate primarily for employment opportunities and professional development (Howe-Walsh and Schyns, 2010, Harvey, 2011). While career development is demonstrated to be one major motive for SIEs to go abroad and career success consequently one major outcome of expatriation (Doherty et al., 2011, Harvey, 2011), there 
has been surprisingly little discussion on SIEs' career success. To address this research gap, the current paper aims to advance the understanding of how SIEs achieve career success in the host country through specific career competencies and resources. Specifically, we propose a model in which the concept of career capital (Inkson and Arthur, 2001) is refined in the context of SIEs and the predicting relationship between career capital and career success is elaborated. After distinguishing fundamental similarities and differences between traditional expatriates and SIEs, we also integrated two key concepts from studies of the former into our framework: cultural adjustment and cultural distance. Whereas cultural adjustment provides a process perspective of how SIEs sequentially achieve career advancement, cultural distance shows macro-contextual influences of different intercultural situations on career management.

The current paper has two objectives: 1) to clarify the concept of SIEs for future research and 2) to introduce a psychological theoretical framework to predict SIEs' career success. To meet the first aim, we begin in the following section with a conceptual discussion to clarify the group under investigation, before introducing the theoretical framework and its foundations. After that, we explain the propositions developed and conclude with a general discussion.

\section{Conceptual differentiations}

Beside traditional AEs, MNCs increasingly use alternative assignment and employment forms that are more flexible (Brookfield Global Relocation Service, 2010). In connection with that, the term SIE emerged (Suutari and Brewster, 2000). At the same time, a growing body of academic research comparing SIEs with traditional expatriates has been discussing differences between these two groups: Compared with AEs, SIEs initiate and arrange expatriation themselves (Inkson et al., 1997), represent a heterogeneous population with a broad spectrum of hierarchy and skill levels (Suutari and Brewster, 2000), usually have no financial allowance for expatriation from their employers (Howe-Walsh and Schyns, 2010), 
and have no definite plan for repatriation when leaving home (Suutari and Brewster, 2000), meaning that their career development is more indeterminate (Richardson and Mallon, 2005). On the other hand, both types of expatriation share a fundamental similarity: work for a significant period of time abroad. To facilitate comparability with AEs, we focused on the population of skilled SIEs.

Apart from comparing SIEs with AEs, research on global mobility and skilled migrants has addressed the phenomenon of SIEs itself (Carr et al., 2005, Al Ariss and Syed, 2011). Although the vast majority of immigration still relates to low-skilled work, the share of tertiary-educated migrants in the OECD countries has been increasing constantly in the last decades, comprising approximately $25 \%$ of foreign-born population in these regions (OECD, 2008). Furthermore, the mobility of skilled migrants has changed from permanent migration to more frequent, temporary, and circular arrangements (OECD, 2008, Saxenian, 2005).

In migration studies, those who move from developing countries to more developed ones are typically defined as migrants, and those who move between developed countries as SIEs (Al Ariss, 2010). Our framework embraces skilled individuals from both developed and developing economies who expatriate themselves for boundaryless careers (Carr et al., 2005). We argue that the most relevant features defining SIEs in our paper are: 1) seeking career advancement as the major driver for moving, and 2) planning a temporary and undefined length of stay outside their home countries (Al Ariss, 2010, Tharenou and Caulfield, 2010). Of course, many SIEs may decide to settle down permanently in the host country and become immigrants for family reasons (Al Ariss and Syed, 2011, Harvey, 2009). Hence, ambiguity coexists between the terms migrant and SIE; the differences depend partly on intrinsic and intangible criteria (e.g. necessity to leave for migrants vs. seeking job challenge for SIEs; see Al Ariss, 2010), meaning that in individual cases, the boundaries are sometimes unclear. 


\section{Theoretical framework}

Our objective was to counter the scarce research on psychological processes in SIEs' career development. The theoretical framework we developed, based on career capital theory (Inkson and Arthur, 2001), explains how SIEs achieve subjective and objective career success during expatriation. Three specific kinds of career capital were identified as predictors for career success, and cultural adjustment was seen to act as a mediator that sequentially predicts SIEs' career success. SIEs from different cultural backgrounds were taken into account as well. Figure 1 presents a simplified version of our proposed framework. In this section, we introduce the relevant theoretical bases and definitions of our key construct and then describe the deduction of the proposed relationships, which are shown as paths in the framework. In the following, we first consider career success and the three career capital components. Second, we elaborate the interaction between the three career capital components and their predicting effect on career success. Third, we identify the mediator and moderator variables in the framework.

\section{[Insert Figure 1]}

\subsection{Career success}

The term career is commonly defined as the sequence of a person's work experiences over time (Arthur et al., 2005). Career success is the outcome of these work experiences during a significant period of time, defined as "the accomplishment of desirable work-related outcomes at any point in a person's work experiences over time" (Arthur et al., 2005, p. 179). Career success can be described in two different ways ( $\mathrm{Ng}$ et al., 2005). Subjective success refers to a person's internal reflection and evaluation across his or her individually relevant dimensions. In career studies, it is often operationalized as career satisfaction. Objective success includes objectively comparable or more tangible indicators of a person's career 
situation, for example, promotion and salary (Arthur et al., 2005). Previous research has shown that these two aspects are interdependent but conceptually distinct ( $\mathrm{Ng}$ et al., 2005).

In the context of a boundaryless career, the personal meaning of one's career advancement has been gaining importance (Arthur et al., 2005, Doherty et al., 2011, Richardson and Mallon, 2005). Compared to AEs, SIEs have strong intrinsic career motivations and personal goals to go abroad (Doherty et al., 2011, Harvey, 2011). Subjective reflection and evaluation of their work-related outcomes is expected to have a high impact on their future career considerations. Hence, subjective career success is the major criteria in the context of SIEs. We integrated both subjective and objective career success in our framework to obtain a more comprehensive representation of the role of SIEs' career capital in their career development.

\subsection{Career capital}

Much has been written about predicting career success. Major sets of variables predicting career success include human capital (e.g. education, professional experiences, and social capital), socio-demographic variables (e.g. age, gender, and marital status), motivational variables (e.g. ambition and work centrality), organizational variables (e.g. HR development programs and supervisor support), and stable individual difference variables (e.g. mental ability and lotus of control, $\mathrm{Ng}$ et al., 2005).

Eby et al (2003) implemented the theoretical framework of career capital (Inkson and Arthur, 2001) to categorize the predictors of career success into three kinds of career competencies: (1) knowing-why, which refers to energy, sense of purpose, motivation, selfconfidence, and evaluation of a certain career path; (2) knowing-whom, which compasses comprehensive networks, relationships, and attachments that people build in their career; and (3) knowing-how, which includes technical, conceptual, and interpersonal skills, expertise, 
tactics, and explicit knowledge that people form in their specific career settings. These three career capital components are interdependent and any one component can be enhanced by the other two (Inkson and Arthur, 2001).

One basic assumption in the literature on global careers is that individuals strive to maximize their career benefit out of work experience for their future vocational life (Suutari and Mäkelä, 2007). International work experience is generally regarded as an effective way to acquire career capital (Dickmann and Harris, 2005). When SIEs leave their country for an international career, they expect to be able to accumulate desirable career competencies and resources during expatriation (Jokinen et al., 2008). We therefore integrated the concept of career capital (Inkson and Arthur, 2001, Jokinen et al., 2008) into our theoretical framework, which offers a useful conceptual underpinning to understand the development of SIEs' career competencies and their outcomes.

From a resource-based perspective, we refined the concept of career capital by describing how some specific career capital components interact with each other and foster SIEs' career success. Specifically, we postulate that protean career attitude as "knowingwhy", career network as "knowing-whom", and cultural intelligence as "knowing-how" career capital predict SIEs' career success in the host country. In the following, we introduce these career capital components and elaborate their proposed relationships in the framework (see Fig. 2).

\section{[Insert Figure 2]}

\subsubsection{Knowing-why: Protean career attitude}

In the last two decades, new career patterns have emerged that are flexible, non-linear, and self-driven. Hall (1996) introduced the concept of the "protean career" that is driven by individuals themselves and "that will be reinvented by the person from time to time, as the 
person and the environment change" (p. 8). According to Briscoe and colleagues (2006), individuals with protean career attitudes are self-directed (taking an independent and proactive role in managing their vocational development) and values-driven (following their own vs. organizational values in career management). The protean career construct emphasizes the intrinsic success of the career. Employability and competency accumulation are more fundamental than job security in career development (Hall, 1996).

Previous research found that persons with a protean career attitude had a proactive personality and were open-minded and motivated in their career management (Briscoe et al., 2006). Moreover, proactivity and openness are positively associated with both objective (salary and promotions) and subjective (career satisfaction) indicators of career success (Seibert et al., 1999, Ng et al., 2005). De Vos and Soens (2008) demonstrated that career selfmanagement (employees' efforts to define and realize their personal career objectives) fully mediates the positive relationship between protean career attitude and career satisfaction.

Since the concept of SIE was first introduced, researchers have accentuated the personal motivations for and the intrinsic career goals of expatriation (Doherty et al., 2011, Inkson et al., 1997, Suutari and Brewster, 2000). For SIEs, we argue that a protean career attitude is one fundamental component of knowing-why career capital that drives and influences the entire career development process during expatriation. SIEs with a protean career attitude are curious to learn about host country cultures, willing to adapt to the new job environment, and show a high degree of personal agency in their expatriation (Cerdin and Pargneux, 2010, Doherty et al., 2011, Inkson et al., 1997). For these reasons, protean career attitude as knowing-why career capital is postulated to foster the other two career capital components: cultural intelligence and career network. Consequently, SIEs with a strong protean career attitude are more likely to achieve subjective and objective career success in the host country. 
Proposition 1a: Protean career attitude has a positive influence on total career network size.

Proposition 1b: Protean career attitude has a positive influence on cultural intelligence.

Proposition 2a: Protean career attitude has a positive influence on both subjective and objective career success.

\subsubsection{Knowing-whom: Career network size}

A network is defined as "the pattern of ties linking a defined set of persons or social actors" (Seibert et al., 2001, p. 220). People have a natural demand to be embedded within a community and social groups (Wang and Kanungo, 2004). Vocational networks inside and outside organizations not only meet this need but also supply individuals with upward mobility and job opportunities (Eby et al., 2003). In migration studies, transnational social networks (i.e. social fields linking homeland and diaspora locations) are considered to be important for skilled migrants' careers and entrepreneurship in the host and home countries (Harvey, 2009, Saxenian, 2005).

In the context of SIE, career-related networks are valuable sources of informative and emotional support (Mäkelä and Suutari, 2009). In addition, intensive interaction with a large number of contacts from diverse cultural, social, and professional backgrounds is expected to benefit SIEs' future careers. Such interactions would not have been possible if they had remained in their home countries (Mäkelä and Suutari, 2009). We therefore postulate that a large and diverse international network is a major form of knowing-whom career capital that SIEs accumulate during expatriation. More specifically, interaction with international network ties can provide resources for acquiring intercultural skills and knowledge and thus increase cultural intelligence. A large career network is also likely to broaden the career horizon and 
provide SIEs with career insights and opportunities that can result in more self-driven career attitudes and independency in career management. Furthermore, social networks have been found to predict career success to a great extent because they serve as emotional support, task assistance, and sources of career information (Seibert et al., 2001). We therefore postulate that career network size influences the other two career capital components and career success positively.

Proposition 1c: Total career network size has a positive influence on protean career attitude.

Proposition 1d: Total career network size has a positive influence on cultural intelligence.

Proposition 2b: Total career network size has a positive influence on subjective and objective career success.

For both AEs and SIEs, one fundamental feature of their social networks is the multicultural context. We sought to elaborate more specifically the role of host and home country nationals in SIEs' career networks. Unlike AEs, SIEs are usually employed in the host country as local employees and rely largely on their personal networks to adjust to the new environment (Howe-Walsh and Schyns, 2010). Hence, host country nationals are assumed to provide SIEs with crucial resources for learning and social support. The influence of home country nationals is expected to be more nuanced and will be discussed in the section on cultural distance.

Proposition 2c: Career network size of host country nationals has a positive influence on subjective and objective career success. 


\subsubsection{Knowing -how: Cultural intelligence}

International work experiences are found to benefit expatriate managers' general global business understanding, intercultural competencies, and general operational and management skills (Suutari and Mäkelä, 2007). SIEs, in contrast, are a much more diverse population with different professional backgrounds and positions; not all of them have management and business career orientations (Richardson, 2009). In their case, the capability to act and interact in intercultural contexts likely represents the most relevant and basic "knowing-how" career capital acquired through international work experience.

There are several constructs representing this capability, such as global mindset, intercultural competency, and cultural intelligence (Thomas et al., 2008). From these, we adopted the concept of cultural intelligence, defined as "a system of interacting knowledge and skills, linked by cultural meta-cognition that allows people to adapt to, select, and shape the cultural aspects of their environment" (Thomas et al., 2008, p.126). The first cultural intelligence component, knowledge, refers to declarative knowledge about the characteristics of cultures and mentally stored general process schemata in specific cultures. Skills are the characteristics of individuals that help them to interact in intercultural contexts. Unlike stable personality traits, skills and cultural intelligence are of developmental and dynamic nature. The third component, cultural metacognition, is defined as "knowledge of and control over one's thinking and learning activities" (Thomas et al., 2008, p.131). It is culturally unspecific and acts as a linking mechanism that regulates interaction of its constituent elements (Thomas et al., 2008). Previous research showed that SIEs' motivation for moving to other countries often includes gathering intercultural knowledge and experiences in a vocational context (Richardson and Mallon, 2005). Through international working contexts, SIEs expect to increase cultural intelligence as a fundamental form of career capital that benefits their future career development (Jokinen et al., 2008). 
In contrast to human capital, knowing-how career capital emphasizes career resources that can be transferred across organizational and even vocational boundaries (Jokinen et al., 2008). Cultural intelligence is assumed to be one such form of transportable career capital. A broad knowledge spectrum about host country cultures and a high level of interaction skills with host country nationals are very likely to enable effective intercultural communication, foster the build-up of a large career network, and ease SIEs into pursuing their career goals across organizational, vocational, and culture boundaries, thereby leading to higher levels of both intrinsic and extrinsic career success.

Proposition 1e: Cultural intelligence has a positive influence on protean career attitude.

Proposition 1f: Cultural intelligence has a positive influence on total career network size.

Proposition 2d: Cultural intelligence has a positive influence on subjective and objective career success.

\subsection{Cultural adjustment}

In studies of traditional expatriation, cultural adjustment is the most prominent indicator of expatriation success and has been the object of much research (Bhaskar-Shrinivas et al., 2005). In our framework, we adapted Black and Gregersen's (1991) tridimensional model of cultural adjustment (general, interaction, and work adjustment). Cultural adjustment is defined as a low level of stress and of negative attitudes associated with living in the host culture and certain changes in behavior (Bhaskar-Shrinivas et al., 2005). This is the primary outcome of expatriation and would influence the development of more distal outcomes such as expatriation satisfaction and job performance (Hechanova et al., 2003). We adapted this construct to the context of SIEs and postulate that cultural adjustment is fundamental in SIEs' 
everyday life and vocational context. More specifically, cultural adjustment acts as a mediator in our framework, being the primary outcome of career capital and a precondition for longterm career success. In the following, we elaborate the sequential predicting relationships between career capital and cultural adjustment and between cultural adjustment and career success.

As mentioned above, individuals with knowing-why career capital in the form of a protean career attitude are open and proactive in adapting to their environments (Seibert et al., 1999). They actualize their behavior and thinking pattern proactively with new norms and standards (Cerdin and Pargneux, 2010). Social networks in the host country as knowingwhom career capital have also been found to have a positive effect on well-being and adjustment during expatriation (Wang and Kanungo, 2004). And cultural intelligence as knowing-how career capital is obviously closely related to cultural adjustment (Thomas et al., 2008). All three components of career capital can therefore be assumed to influence SIEs' cultural adjustment positively. Additionally, adjustment to the job during expatriation is one indicator of individual success (Cerdin and Pargneux, 2009). In our framework, cultural adjustment is considered to be a fundamental initial step for SIEs' career management in the host country. Successful cultural adjustment is expected to influence SIEs' long-term career success positively.

Propositions 3a, b, and c: Cultural adjustment partially mediates the relationship between the three components of career capital (protean career attitude, total career network size, and cultural intelligence) and subjective/objective career success.

\subsection{Cultural distance}

In studies of traditional expatriates, the effect of "cultural distance", "culture novelty" and "cultural toughness" on adjustment has been extensively examined (e.g. Black and Gregersen, 1991). However, in the literature on SIEs, the majority of the samples are skilled 
people who move between countries that are culturally rather similar (e.g. Australian in other English-speaking countries, in Tharenou and Caulfield, 2010). Little is known about SIEs who move between culturally distant regions.

We introduce country-level cultural distance in our framework to call attention to the macro-contextual impact of culture when studying SIEs' career development. Cultural distance refers to basic differences between cultures, such as value systems, beliefs, customs, and rituals in addition to legal, political, and economic systems (House et al., 2004, Shenkar, 2001). Specifically, we postulate that SIEs' career development also differs according to the cultural distance between the host and home country cultures.

\subsubsection{Moderation between career capital and cultural adjustment}

Studies of traditional expatriation have found that the cultural distance makes it easier to adjust to some cultures than to others: A large cultural distance requires more transitions and changes in thoughts and behavior patterns, which creates more problems and stress than in a country with a similar culture (Bhaskar-Shrinivas et al., 2005, Black and Gregersen, 1991). According to the conservation of resource theory (Hobfoll, 2001), the loss of resources (e.g. familiar cultural environment and social support) in a new environment causes adjustment stress. To cope with the stress, new resources are required. We assume that with increasing cultural distance, more resources from the home country are no longer available and must be replaced or substituted in order to adjust to the host country culture. Consequently, the three components of career capital are more crucial for successful adjustment when cultural distances are large than when they are small.

Propositions 4a, b, and c: Cultural distance acts as a moderator for the positive relationship between the three components of career capital (protean career attitude, total career network size and cultural intelligence) and cultural adjustment. For SIEs with large cultural distances, the positive relationship is stronger than for SIEs with smaller cultural distances. 
As mentioned above, we also sought to describe the influence of different cultural backgrounds within networks on career success. Wang and Kanungo (2004) discovered that an active and balanced network, composed of both local people and peer expatriates from the same cultural background, contributed to expatriates' psychological well-being and their assignment success. However, with a large cultural distance, it becomes increasingly difficult for expatriates to communicate unambiguously in the host culture. Interactions with host country nationals from distant cultures are expected to be more difficult and stressful than interactions with host country nationals from similar cultures (Ang et al., 2007). Hence, we postulate that for SIEs from more distant cultures, contacts with members of their own country provide more efficient emotional and informational support for overcoming expatriation difficulties than contact with host country nationals. In contrast, SIEs from culturally similar countries may acquire information and support more efficiently from host country nationals. For them, home country nationals do not have the same importance as for SIEs from culturally distant regions.

Proposition 4d: Cultural distance acts as a moderator for the relationship between career network size of home country nationals and cultural adjustment. For SIEs with large cultural distances, the career network size of home country nationals is more positively related to cultural adjustment than for SIEs with small cultural distances.

\subsubsection{Moderation between cultural adjustment and career success}

As mentioned above, expatriation to a culturally distant country causes more challenges and stress than expatriation to a country with a similar culture (Bhaskar-Shrinivas et al., 2005, Black and Gregersen, 1991). Consequently, for SIEs with large cultural distances, successful cultural adjustment is crucial to further expatriation outcomes, that is, to career success in our framework. This positive relationship is weaker for SIEs from similar cultures, for whom cultural adjustment is much less of a challenge. 
Proposition 4e: Cultural distance acts as a moderator for the positive relationship between cultural adjustment and subjective and objective career success. For SIEs with large cultural distances, this positive relationship is stronger than for SIEs with smaller cultural distances.

\section{Conclusions}

Since the last recession, many national economies have become unstable and unpredictable. For MNCs, it is even more crucial to have the right people at the right place at the right time. Self-initiated expatriation is therefore expected to continue playing an important role (Deloitte, 2010). We believe that our framework provides a better conceptual understanding of this new trend, thereby contributing to both theory and practice. In the following sections, we first discuss the research contribution of our paper, then its practical implications. Finally, we elaborate the limitations and further research suggestions.

In the present paper, we first sought to provide a conceptual clarification of the differences between AEs, SIEs and migrants. By integrating literature in human resource management (e.g. Howe-Walsh and Schyns, 2010), international career studies (e.g. Carr et al., 2005), and migration studies (e.g. Harvey, 2011), the current paper contributes to a more differentiated understanding of SIEs.

Second, we aimed to understand how these individuals use their career resources and competencies to achieve career success in the host country. In this respect, the current paper makes three major research contributions: 1) Although extant research has acknowledged the importance of career capital in SIEs' career development (Jokinen et al., 2008, Suutari and Mäkelä, 2007), it has not provided any comprehensive theoretical explanation of how career capital interplays with and acts on SIEs' career success. Having adopted career capital theory (Inkson and Arthur, 2001) to provide the conceptual underpinnings, our model describes how 
the specific career capital components interact and predict SIEs' career success. From a resource-based perspective, we sought to conceptually identify those career resources and competencies that are of fundamental importance for SIEs during their international work experiences. Three concepts, protean career attitude (Hall, 1996), career network (Seibert et al., 2001) and cultural intelligence (Thomas et al., 2008) are identified as the relevant career capital components in our framework. 2) After reviewing the traditional expatriation literature, we also emphasize the importance of cultural adjustment (Black and Gregersen, 1991) in our conceptual framework. In the process of SIEs' career development in the host country, cultural adjustment is the primary outcome of expatriation in our model and mediates the predicting effect of career capital on career success. 3) As Tharenou and Caulfield (2010) pointed out, one macro-contextual factor - intercultural career context - has been largely neglected in previous SIE research. We integrated the macro-contextual level into the framework and emphasize the influence of cultural distance (Shenkar, 2001) on SIEs' career development. With this multi-level approach, we offer a more context-specific view of different career development strategies.

\subsection{Practical implications}

Our framework has three main practical implications for governments, organizations and individuals: First, the framework identified three kinds of career resources and competencies that SIEs try to maximize as "investments" for future career advancement. Organizations and receiving countries should understand the different individual career development needs and provide opportunities to increase career capital during expatriation. If SIEs can fulfill their career goals in accordance with their intrinsic values and preferences, corporations and host countries may attract and retain these skilled individuals in the long term. This implication impacts strategies and tactics in international talent acquisition and retention, a key challenge faced by human resource management, policy makers, and societal 
associations. Second, from a resource-based perspective, our framework indicates that the three specific components of career capital should facilitate SIEs' expatriation adjustment. It emphasizes the sequential process of SIEs' intercultural career development and the critical importance of career adjustment in that process. Specifically, the framework suggests how to adjust to the host country culture in order to meet further goals (e.g. performance and job satisfaction from an organizational perspective and career advancement from an individual perspective). Third, our framework reveals the differentiated functions of SIEs' multi-cultural career networks. Organizations and policy makers need to be aware of the cultural distance each SIE experiences. Specifically, governments, societal associations, and organizations should provide SIEs who are experiencing large cultural distances with channels for finding and establishing transnational social ties.

\subsection{Limitations and further research}

This paper has several limitations. First, when applying career capital theory to provide a conceptual underpinning for explaining SIEs' career success, we did not integrate other relevant variables, such as family ties, social relationships, and the labor market in the home country. Their omission by no means implies that they have no impact on SIEs' career success. The importance of family influence and macro-economic context on career development for SIEs has already been confirmed in previous research (e.g. Harvey, 2009). A second limitation concerns the developmental and dynamic nature of career capital and career success. Although we did not explicitly incorporate time in our framework, we recognize its importance in SIEs' career development process.

All in all, the contributions and limitations of our framework open several new avenues of research: First of all, empirical studies are encouraged in order to test our theoretical framework. Second, given that self-initiated expatriation is a life event that is influenced not only by career-related aspects, but also by family relationships, lifestyle, and even 
individuals' basic values, the role of such factors could be integrated into a holistic approach to study SIEs' career development. Third, a longitudinal study would also help to better understand career development across different stages of working life. For example, future research could study 1) the process of how SIEs maximize their career capital during expatriation, and 2) the effect of career capital accumulation on later career advancement. Finally, we recommend more in-depth studies on components of career capital at an organizational and country level. Research could focus on 1) organizational factors motivating skilled people to migrate, to stay long-term in the host country, and to repatriate, and 2) the contribution of accumulated career capital to achieving organizational goals. 


\section{References}

Al Ariss, A. (2010), "Modes of engagement: Migration, self-initiated expatriation, and career development", The Career Development International, Vol. 15 No. 4, pp. 338-358

Al Ariss, A. \& Syed, J. (2011), "Capital mobilization of skilled migrants: A relational perspective", British Journal of Management, Vol. 22 No. 2, pp. 286-304.

Ang, S., Van Dyne, L., Koh, C., Ng, K. Y., Templer, K. J., Tay, C. \& Chandrasekar, N. A. (2007), "Cultural Iitelligence: Its measurement and effects on cultural judgment and decision making, cultural adaptation and task performance", Management and Organization Review, Vol. 3 No. 3, pp. 335-371.

Arthur, M. B., Khapova, S. N. \& Wilderom, C. P. M. (2005), "Career success in a boundaryless career world", Journal of Organizational Behavior, Vol. 26 No. 2, pp. 177-202.

Bhaskar-Shrinivas, P., Harrison, D. A., Shaffer, M. A. \& Luk, D. M. (2005), "Input-based and time-based models of international adjustment: Meta-analytic evidence and theoretical extensions", Academy of Management Journal, Vol. 48 No. 2, pp. 257-281.

Black, J. S. \& Gregersen, H. B. (1991), "Antecedents to cross-cultural adjustment for expatriates in Pacific Rim assignments", Human Relations, Vol. 44 No. 5, pp. 497515.

Briscoe, J. P., Hall, D. T. \& Frautschy DeMuth, R. L. (2006), "Protean and boundaryless careers: An empirical exploration", Journal of Vocational Behavior, Vol. 69 No. 1, pp. $30-47$.

Brookfield Global Relocation Service (2010), "Global relocation trends 2010 survey report", available at: http://espritgloballearning.com/wpcontent/uploads/2011/03/2010_GlblReloTrendsSurvey.pdf (accessed 5 September 2011). 
Carr, S. C., Inkson, K. \& Thorn, K. (2005), "From global careers to talent flow: Reinterpreting 'brain drain'", Journal of World Business, Vol. 40 No. 4, pp. 386-398.

Cerdin, J.-L. \& Pargneux, M. L. (2010), "Career anchors: A comparison between organization-assigned and self-initiated expatriates", Thunderbird International Business Review, Vol. 52 No. 4, pp. 287-299.

De Vos, A. \& Soens, N. (2008), "Protean attitude and career success: The mediating role of self-management", Journal of Vocational Behavior, Vol. 73 No. 3, pp. 449-456.

Deloitte (2010), "Talent Edge 2020: Blueprints for the new normal", available at: http://www.deloitte.com/view/en_US/us/Services/additional-services/talent-humancapital-hr/Talent-Library/talent-edge-2020/index.htm (accessed 8 September 2011).

Dickmann, M. \& Harris, H. (2005), "Developing career capital for global careers: The role of international assignments", Journal of World Business, Vol. 40 No. 4, pp. 399-408.

Doherty, N., Dickmann, M. \& Mills, T. (2011), "Exploring the motives of company-backed and self-initiated expatriates", The International Journal of Human Resource Management, Vol. 22 No. 3, pp. 595-611.

Eby, L. T., Butts, M. \& Lockwood, A. (2003), "Predictors of success in the era of the boundaryless career", Journal of Organizational Behavior., Vol. 24 No. 6, pp. 689708.

Hall, D. T. (1996), "Protean careers of the 21st century", The Academy of Management Executive (1993-2005), Vol. 10 No. 4, pp. 8-16.

Harvey, W. S. (2009), "British and Indian scientists in Boston considering returning to their home countries", Population, Space and Place, Vol. 15 No. 6, pp. 493-508.

Harvey, W. S. (2011), "British and Indian scientists moving to the United States", Work and Occupations, Vol. 38 No. 1, pp. 68-100. 
Hechanova, R., Beehr, T. A. \& Christiansen, N. D. (2003), "Antecedents and consequences of employees' adjustment to overseas assignment: A meta-analytic review", Applied Psychology: An International Review, Vol. 52 No. 2, pp. 213-236.

Hobfoll, S. E. (2001), "The influence of culture, community, and the nested-self in the stress process: Advancing Conservation of Resources theory", Applied Psychology: An International Review, Vol. 50 No. 3, pp. 337-421.

House, R. J., Hanges, Javidan, Dorfman \& Gupta (2004). Culture, leadership, and organizations : The GLOBE study of 62 societies, Sage, Thousand Oaks, Calif.

Howe-Walsh, L. \& Schyns, B. (2010), "Self-initiated expatriation: Implications for HRM", The International Journal of Human Resource Management, Vol. 21 No. 2, pp. 260273.

Inkson, K. \& Arthur, M. B. (2001), "How to be a successful career capitalist", Organizational dynamics., Vol. 30 No. 1, pp. 48-61.

Inkson, K., Arthur, M. B., Pringle, J. \& Barry, S. (1997), "Expatriate assignment versus overseas experience: Contrasting models of international human resource development", Journal of World Business, Vol. 32 No. 4, pp. 351-368.

Jokinen, T., Brewster, C. \& Suutari, V. (2008), "Career capital during international work experiences: Contrasting self-initiated expatriate experiences and assigned expatriation", International Journal of Human Resource Management, Vol. 19 No. 6, pp. 979-998.

Mäkelä, K. \& Suutari, V. (2009), "Global careers: A social capital paradox", International Journal of Human Resource Management, Vol. 20 No. 5, pp. 992-1008.

Ng, T. W. H., Eby, L. T., Sorensen, K. L. \& Feldman, D. C. (2005), "Predictors of objective and subjective career success: A meta-analysis", Personnel Psychology, Vol. 58 No. 2, pp. 367-408.

OECD (2008). The global competition for talent, OECD, Paris. 
Richardson, J. (2009), "Geographic flexibility in academia: A cautionary note", British Journal of Management, Vol. 20, pp. S160-S170.

Richardson, J. \& Mallon, M. (2005), "Career interrupted? The case of the self-directed expatriate", Journal of World Business, Vol. 40 No. 4, pp. 409-420.

Saxenian, A. (2005), "From brain drain to brain circulation: Transnational communities and regional upgrading in India and China", Studies in Comparative International Development (SCID), Vol. 40 No. 2, pp. 35-61.

Seibert, S. E., Crant, J. M. \& Kraimer, M. L. (1999), "Proactive personality and career success", Journal of Applied Psychology, Vol. 84 No. 3, pp. 416-427.

Seibert, S. E., Kraimer, M. L. \& Liden, R. C. (2001), "A social capital theory of career success", Academy of Management Journal, Vol. 44 No. 2, pp. 219-237.

Shenkar, O. (2001), "Cultural distance revisited: Towards a more rigorous conceptualization and measurement of cultural differences", Journal of International Business Studies, Vol. 32 No. 3, pp. 519-535.

Suutari, V. \& Brewster, C. (2000), "Making their own way: International experience through self-initiated foreign assignments", Journal of World Business, Vol. 35 No. 4, pp. 417436.

Suutari, V. \& Mäkelä, K. (2007), "The career capital of managers with global careers", Journal of Managerial Psychology, Vol. 22 No. 7, pp. 628-648.

Tharenou, P. \& Caulfield, N. (2010), "Will I stay or will I go? Explaining repatriation by selfinitiated expatriates", Academy of Management Journal, Vol. 53 No. 5, pp. 10091028.

Thomas, D. C., Elron, E., Stahl, G., Ekelund, B. Z., Ravlin, E. C., Cerdin, J.-L., Poelmans, S., Brislin, R., Pekerti, A., Aycan, Z., Maznevski, M., Au, K. \& Lazarova, M. B. (2008), "Cultural intelligence: Domain and assessment", International Journal of Cross Cultural Management, Vol. 8 No. 2, pp. 123-143. 
Wang, X. \& Kanungo, R. N. (2004), "Nationality, social network and psychological wellbeing: Expatriates in China", The International Journal of Human Resource Management, Vol. 15 No. 4-5, pp. 775-793. 


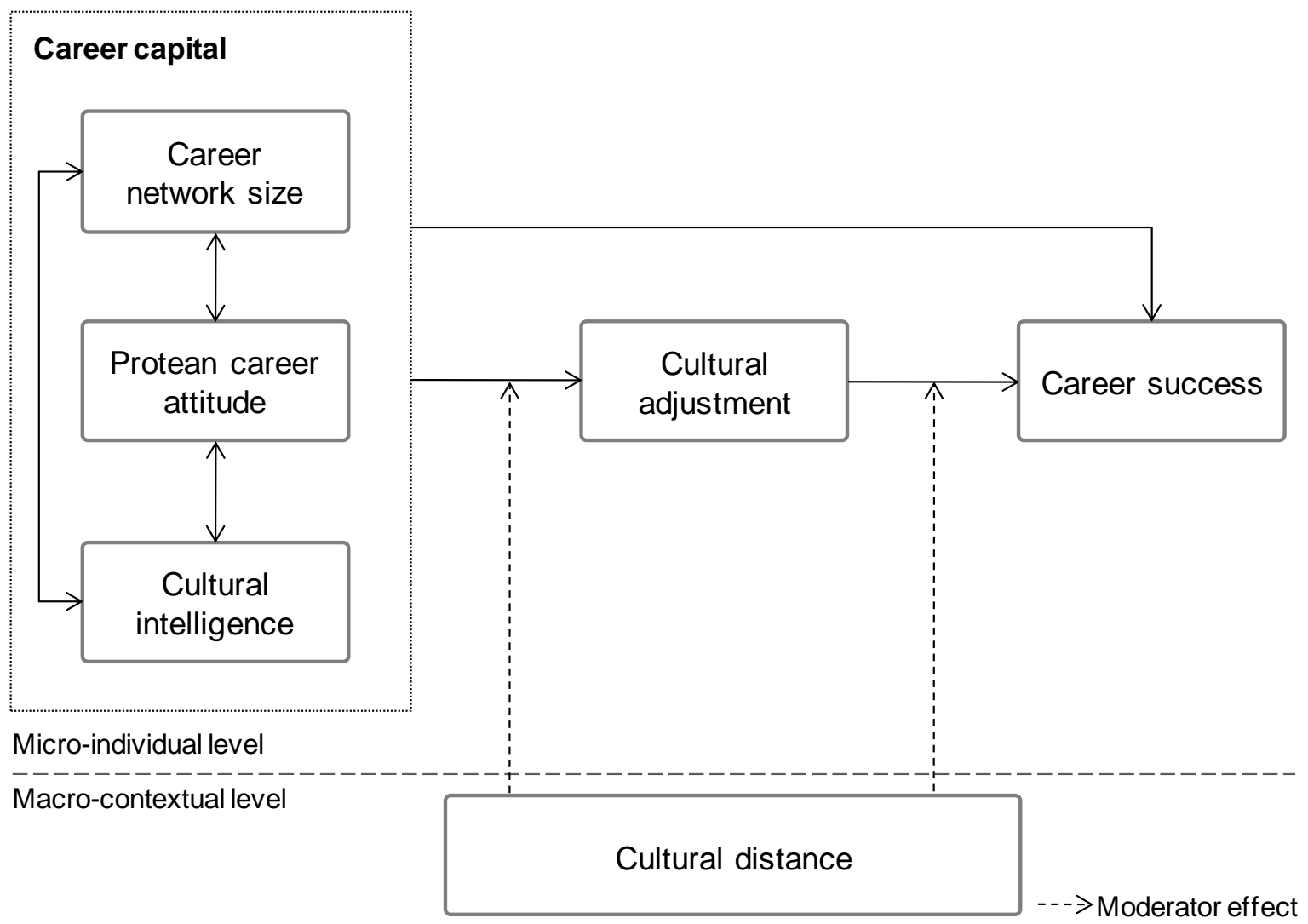

Figure 1: Simplified version of the conceptual framework. 


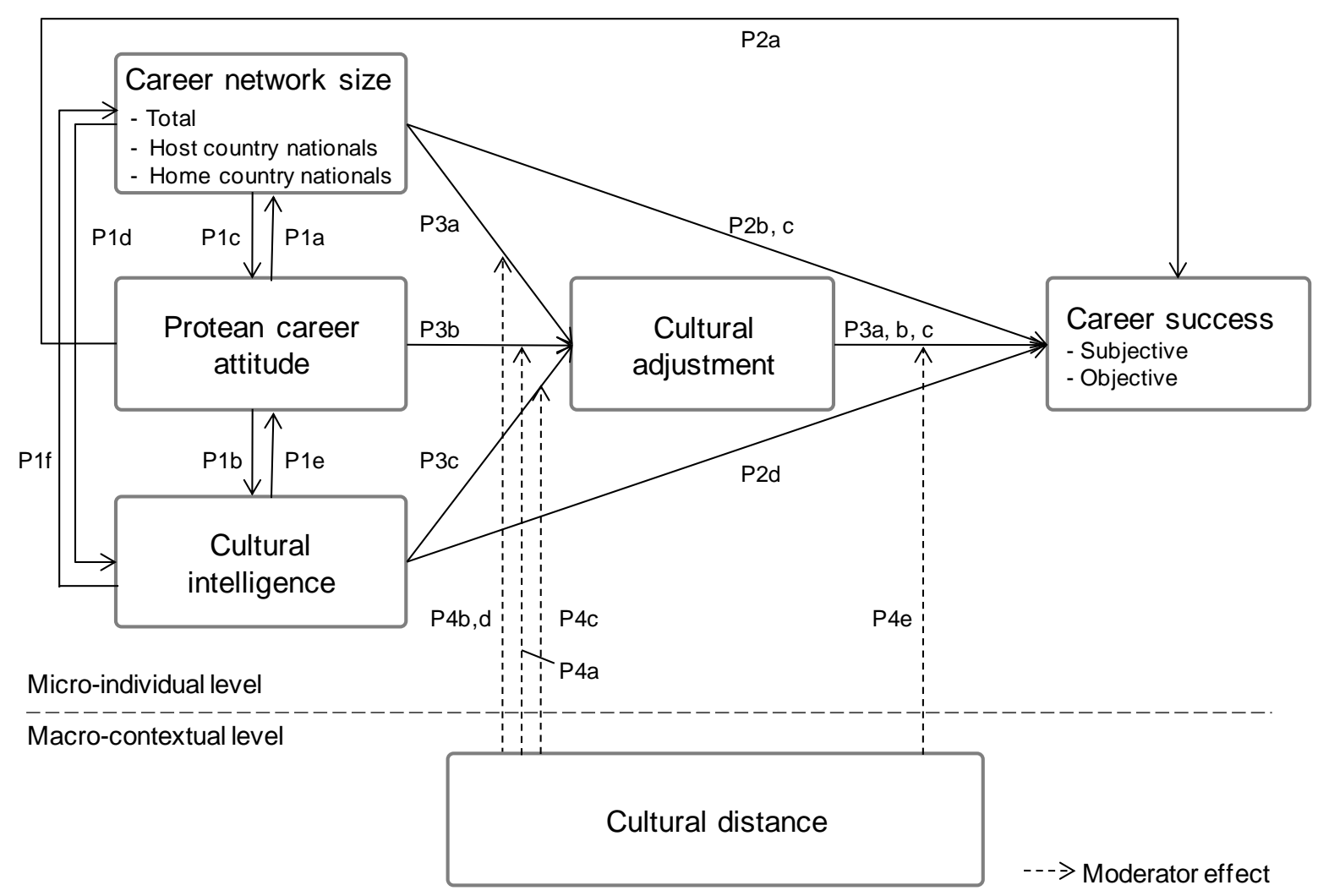

Figure 2: Conceptual framework with propositions predicting career success for SIEs. "P" represents numbered propositions. 